Clinically it is important to be able to differentiate this condition from tabes. As a rule this is very easy for the tabetic pupil is nearly always bilateral, the myotonic nearly always mono-lateral. In tabes when the knee jerks and ankle jerks are absent there is always Rhombergism. In the myotonic pupil syndrome even when both pupils are affected, and the knee jerks and ankle jerks are absent, neither Rhombergism nor sensory symptoms are present.

It has been suggested that since, as far as the pupillary reactions are concerned, the lesion is probably in the ciliary ganglion, "Ciliary Ganglion Irido-plegia" is a better name for the syndrome (Brit. $\mathrm{Jl}$. of Ophthal., February, 1942).

Yours faithfully,

Percival W. Leathart.

31, RODNEY STREET,

LIVERPOOL, 1.

November 15, 1942.

\title{
PRONTOSIL SOLUBLE IN CONJUNCTIVITIS
}

To the Editors of THE BRITISH JOURNAL OF OPHTHALMOLOGY.

DEAR SiRs,-The article by J. Horton Young, R.A.M.C., which appeared in the June issue of the Journal is full of interest.

I have already sent to the Medical Journal of Australia an account of the value of prontosil soluble $2 \frac{1}{2}$ per cent. in conjunctivitis, and the use of finely strained sulphanilamide in cod liver oil in corneal ulceration. But as indicated in that sketch the puzzle is to. know what the prontosil really does.

In the most severe, and to me unique case of conjunctivitis I have ever seen it was most effective, but two thorough bacteriological investigations showed nothing but diphtheroid organisms and some polymorph cells.

I refer also to the experimental work of Robson and Scott published in Nature, April 22, 1942.

Apparently prontosil is absorbed by the conjunctiva rapidly, and effects some favourable change. As indicated, I have been using it in a severe case of spring catarrh with success. It seemed to me that administration orally was not logical as one only hopes that it will reach the eye, whereas the local administration deals directly with the diseased tissue and in any event administration by the mouth in a protracted case would be dangerous.

I have found, as J. Horton Young has found, that it does not irritate, nor does it interfere with any other drops that may be used. About its use in deep infection of the eye I have no experience at present. It is too much to expect that we have found a universal 
remedy for diverse eye conditions but we can keep an open mind on the subject.

I am, etc.,

JAMES W. BARRETT.

MELBOURNE,

August 20, 1942.

\section{UNUSUAL CASES OF CONJUNCTIVITIS}

To the Editors of THE BRITISH JOURNAL OF OPHTHALMOLOGY.

DEAR SIRS, - In your October issue, Major E. F. King discusses four unusual cases of conjunctivitis in soldiers showing certain common features, which he thinks "group them as a clinical entity." In the last sentence of the conclusions he indicates that " the condition" is obscure in pathogenesis but expresses an interest in finding out if other surgeons have met with similar cases. This paragraph assumes the existence of a condition or entity into which his cases fit, but obviously is meant to welcome other opinion. Having a long-standing interest in the aetiology of conjunctival disease, I venture to trespass on your space by offering some remarks. To be frankly critical I cannot see why these four cases should constitute a "group," "clinical entity" or "condition," and although I support Major King's idea in urging an attitude of enquiry towards the unfamiliar conjunctival affections which we are all liable to meet, I deplore any suggestion which might tend to establish another clinical conjunctival group on four cases, such as that named after Parinaud by H. Gifford in 1898.

Cases 1 and 4 appear, prima facie, to be so different as to make them mutually exclusive of any purely clinical group or entity. Conversely Case 1 resembles some published descriptions of Parinaud's syndrome so much more than it resembles Case 4 , that it fits relatively well into that clinical picture. For the sake of clearness it may be recalled that the modern conception of a Parinaud's conjunctivo-glandular (or oculo-glandular) syndrome is based on three cases published by Parinaud in 1889 which appeared to him to form a clinical group.* Since then numbers of cases showing similar clinical features have been investigated by different observers with a view to isolating what one might term specific aetiological entities from the parent generic clinical group. Eventually, as S. Gifford pointed out, the Parinaud syndrome resolved itself into a complex consisting of an aetiologically proven group, such as Verhoeff's Leptothricosis conjunctivae, certain cases of conjunctival tuberculosis, Pascheff's conjunctivitis necroticans, conjunctival tularensis, etc., plus an unproven residue into which,

* (cf. H. Gifford, Brit. Jl. of Ophthal., p. 350, 1924)', 